\title{
A TALE OF TWO CITIES: HISTORICAL NARRATIVES IN THE RUSSIAN AND CHINESE URBAN LANDSCAPES
}

\author{
Chen Fachun \\ Tianjin Foreign Studies University, Tianjin, China
}

Olga A. Leontovich

Volgograd State Socio-Pedagogical University, Volgograd, Russia; Tianjin Foreign Studies University, Tianjin, China

\begin{abstract}
The present paper is part of a broader research "Language of a Big City: Media Urban Discourse in Russia and China". Its theoretical basis is situated in the contact zone between narratology, critical discourse analysis, semiotics and urban communication studies. The investigation is carried out on the example of two big non-capital cities - Volgograd and Tianjin, which represent the social processes typical of modern urban communities. The research model used for the study includes the following dimensions: 1) types of urban narratives; 2) narrator; 3) audience (reader / listener / viewer); 4) plot; 5) time; 6) space; 7) types of semiotic signs; 8) intertextual connections. The investigation proceeds from the idea about the textuality of the human mind, as well as the narrative ways of reality and identity construction. Multiple narratives can provide different urban history interpretations. Politicians use narratives to appropriate or reshape the past and the present as a common form of manipulation. A specific feature of urban historical narratives is that they do not possess fixed temporal boundaries and change due to the dynamics of urban social life. We argue that the stories that shape memories in the minds of general public are condensed versions of historical narratives based on the most intensely remembered facts, coloured with emotions and intensified by visual images, impressions and intertextual links. This idea emphasises the social responsibility of the creators of modern urban narratives in their different forms. The perspective of the research is to investigate the connection of these processes with Russian and Chinese mentality, values, logic of meaning-making and linguistic expression.

Key words: urban landscape, media urban communication, historical memories, narrative, semiotic signs, Russia, China.

Citation. Chen Fachun, Leontovich O.A. A Tale of Two Cities: Historical Narratives in the Russian and Chinese Urban Landscapes. Vestnik Volgogradskogo gosudarstvennogo universiteta. Seriya 2. Yazykoznanie [Science Journal of Volgograd State University. Linguistics], 2020, vol. 19, no. 2, pp. 78-85. DOI: https://doi.org/ 10.15688/jvolsu2.2020.2.7
\end{abstract}

\section{ПОВЕСТЬ О ДВУХ ГОРОДАХ: ИСТОРИЧЕСКИЕ НАРРАТИВЫ В РОССИЙСКОМ И КИТАЙСКОМ ГОРОДСКОМ ЛАНДШАФТЕ}

\author{
Чэнь Фачунь \\ Тяньцзиньский университет иностранных языков, г. Тяньцзинь, Китай
}

\section{Ольга Аркадьевна Леонтович}

Волгоградский государственный социально-педагогический университет, г. Волгоград, Россия; Тяньцзиньский университет иностранных языков, г. Тяньцзинь, Китай

Аннотация. Настоящая статья представляет собой часть исследовательского проекта «Язык большого города: медиаурбанистический дискурс в России и КНР» и опирается на положения нарратологии, крити- 
ческого дискурс-анализа, семиотики и теории коммуникации. Изыскание проводится на материале двух крупных нестоличных городов - Волгограда и Тяньцзиня, жизнь которых ярко отражает социальные процессы в современных урбанистических сообществах. Цель статьи - выявить роль исторических нарративов в конструировании имиджа города и идентичности его жителей. В основе анализа лежит идея о текстуальности сознания и нарративных способах конструирования мира и человеческой идентичности. Исследовательская модель включает следующие параметры анализа: 1) типы городских нарративов; 2) нарратор; 3) аудитория (читатель / слушатель / зритель); 4) сюжет; 5) время; 6) пространство; 7) типы семиотических знаков; 8) интертекстуальные связи. Показано, что множественные нарративы обеспечивают неоднозначную интерпретацию исторических событий и могут использоваться в политических целях для реконцептуализации прошлого и настоящего. Формирование имиджа города осуществляется на основе «конденсированных» версий исторических нарративов, окрашенных эмоциями и опирающихся на общеизвестные факты, визуальные образы и интертекстуальные связи, что указывает на социальную ответственность создателей современных городских нарративов в различных формах их воплощения.

Ключевые слова: городской ландшафт, медиаурбанистическая коммуникация, историческая память, нарратив, семиотические знаки, Россия, Китай.

Цитирование. Чэнь Фачунь, Леонтович О. А. Повесть о двух городах: исторические нарративы в российском и китайском городском ландшафте // Вестник Волгоградского государственного университета. Серия 2, Языкознание. - 2020. - Т. 19, № 2. - С. 78-85. - (На англ. яз.). - DOI: https://doi.org/10.15688/jvolsu2.2020.2.7

\section{Goals and insights}

Narrativity is the ability of a human mind to conceptualize reality through stories told, heard or visualized from different perspectives. The present paper is part of a broader research project "Language of a Big City: Media Urban Discourse in Russia and China" the theoretical foundations of which are situated in the contact zone between critical discourse analysis, narratology, semiotics and urban communication studies. The latter is a rapidly developing field of research based on the conjunction between urban studies and communication studies. The unity of the two disciplines allows scholars to achieve a better understanding of the social, economic and cultural processes taking place in modern urban areas. A distinct conceptual emphasis on this approach provides an opportunity to formulate the analytical framework of the research and discover the role of narratives in constructing the image of a big city as an existential space. We view a city as a complex communicative system representing a variety of channels, forms and means of human interaction, "a text" in a broad sense of the term [Aiello, Tosoni, 2016; Leontovich, 2018].

The topics discussed in the research project include: factors which influence the formation of a modern city's image [Bakumova, 2018; Leontovich, 2019b]; urban social stratification and its linguistic expression [Kotelnikova, Bakumova, 2019]; semiotics of surveillance as a communicative practice reflecting urban power relations
[Leontovich, 2018]; new urban communication practices as a reflexion of social change [Leontovich, 2019a; Kotelnikova, 2019], etc.

The study is done on the example of two big non-capital cities - Tianjin (China) and Volgograd (Russia), which, from our point of view, represent the social processes typical of modern urban communities. Alongside with the adoption of modern globalization practices, they still preserve linguistic and cultural traditions, which to a certain extent counterbalance cosmopolitanism.

The present paper focuses on the role of urban narratives in preserving historical memories which shape the city's image and the self-identity of its inhabitants. Its aim is to lay out theoretic foundations for the further research of memories integrated and conceptualized in the urban landscapes of Tianjin and Volgograd.

\section{Theoretical background and methodology}

Narratives play an important role in the perception of reality and human life as an ongoing process of interaction with other people. Scholars write about narrative ways of world perception and the textuality of the human mind as a means of reality and identity construction according to the laws of a literary text [Ilyin, 2001]. Human existence and an individual's relationship with the world open up through narratives with the help of the language which expresses the inner motives of human behaviour. It is through narratives that 
people give social practices form and meaning, temporal and logical structure. Narratives act as a mechanism of organization for human experience, they "possess social instrumentality and pragmatic potential" [Lyotard, 1998].

Scholars compare narratives to a universe which consists of one or several worlds. Those worlds are quite real, autonomous and ruled by their own laws which define social dynamics. The versatile and multidimensional character of narratives accounts for the existence of numerous approaches to their definition. G. Genette points out that a narrative is a representation of a real or fictional event or a number of events [Genette, 1976]. This definition focuses on the event-based essence of the narrative. D. Bordwell indicates that events are linked into a chain and are in a causal relationship [Bordwell, 2004]. If we further continue the theme of causality, it can be noted that a narrative is not a mere linear representation of events but a form of communication in which events and their sequence are conditioned and lived by the characters. It is possible to conclude that a narrative is based on a representation of causally connected real or fictional events which happen to the characters.

Narratological literature often contains such terms as story, life history and storying. The notion of story occupies an important place in Western communication studies, psychology, sociology, medicine, literary studies, etc. G. Pradl points out that stories serve as a means of human identity construction: " 'storying' is central to personal and ethical development" [Pradl]. Those stories may change while a person constructs social reality and moves from one life theme to another. Life history research is an important sphere of narrative analysis which can refer to separate episodes, their interconnection and human life in general.

In recent years, the idea of the narrative conceptualization of reality has been gaining popularity. Narratives allow us to get deeply immersed in other people's experiences. They are also powerful enough to be able to change people's lives. As the American swimmer and Olympic champion Chris Cavanaugh puts it, "telling stories is a universally accessible means through which people make meaning".

Social constructs are in many ways conditioned by the culture in which they are produced. An individual's social world is constructed on the basis of the following factors: 1) objective reality; 2) its collective perception by members of a particular community through the prism of their values, beliefs, ideologies and economic relations; 3) an individual's personal attitudes. All these three factors are closely connected with culture: the objectively existing world as a medium of human existence possesses its culture-specific peculiarities embedded in the landscape, architecture, climatic conditions, people's physiological appearance and their language; the collective features uniting members of a community are culturally conditioned.

The ideas discussed above form the theoretical foundation of the present research. Alongside with narratological analysis, the methods we employ include ethnographic, semiotic and critical discourse analyses. The material of the research embraces different types of narratives about the history of Tianjin and Volgograd, their past, present and future, sequence of events, and different stages of their history.

The research model used for the present study includes the following dimensions: 1) types of urban narratives; 2) narrator; 3) audience (reader / listener ( viewer); 4) plot; 5) time; 6) space; 7) types of semiotic signs; 8) intertextual connections.

\section{Landscapes of memory}

The historical memories, cultural heritage, globalization tendencies and local trends in both Tianjin and Volgograd's urban landscapes embody a multidimensional relationship between war and peace, the past, present and future, memories and contemporary issues. As G. Modan puts it, "city streets are texts that are written in words, images, and architectural features" [Modan, 2017, p. 15]. We use the term landscapes of memory introduced by G. Dickinson who indicates that "the present moment is characterized by a deep desire for memory" [Dickinson, 1997, p. 1].

Volgograd's three historical names (Tsaritsyn, Stalingrad, Volgograd) are all represented in its landscape and are associated with different periods of the city's existence. The Volgograd city centre is constructed to create an ensemble built around the emotion-laden memories of the Stalingrad Battle (1942-1943). The major historical 
landmarks include the Square of the Fallen Fighters, the Panorama of the Stalingrad Battle, the ruined mill and Pavlov House, all of which are crowned by Mamayev Hill with the huge Statue of the Motherland. The newly constructed central stadium is associated with the 2018 FIFA World Cup - a significant event in Volgograd's contemporary life.

In Tianjin, ancient history coexists with modernity representing what G. Dickinson calls "multiple layers of memories" [Dickinson, 1997, p. 14]. The city was officially christened the present name to mean "the emperor's ferry" in 1404 by Emperor Yongle, the third emperor of the Ming Dynasty (1368-1644), to commemorate the beginning of his victorious war to the crown, although the place became inhabited for the salt industry during the Western Han Dynasty (202 BC $A D$ 24) and became a shipping hub in North China in the Eastern Han Dynasty (AD 25 -220). Tianjin witnessed modern Chinese history to every detail. After the Second Opium War (1856-1860), Western powers including the UK, France, the USA, Germany, Italy, Russia, Japan, the AustroHungarian Empire and Belgium established concessions in the city from 1860 to 1945 , mainly in a rectangular area in the south of the contemporary downtown, creating a unique cityscape known as the Five Avenues (五大道), which feature the Renaissance, Greek, Gothic, Romantic, Eclectic, and Carson architectures - today's ideal tourist attractions. Another similar area is the Little Italia (意式风情区) across the river, overlooking the Ancient Culture Street (古文化街), a shopping street of traditional Chinese architecture renovated in the 1980s with the Queen of Heaven Palace (天后宫, a temple for the goddess of the sea) at its centre. Landmarks such as the Centennial Clock, the Cultural Square and the Tianjin Eye - a giant Ferris wheel - are the icons of the present.

The types of narratives connected with urban histories include ancient manuscripts; memoirs; scholarly and literary narratives; poetry; war-time newspapers and leaflets; narrative songs; museum expositions and memorials; guided tours; inscriptions on monuments and statues; photo narratives, including pictures on boxes of local chocolates; commentaries in restaurant menus, children's narratives, etc. Narratives reflect the city's ethnic, cultural and linguistic diversity. They can be devoted to people's interpersonal relations, religious beliefs, entertainment, growth of new communication forms, surveillance practices, dangerous and safe urban areas, political life and so on. The research of those narratives may be carried out from the historical, creative, ethical, political, social and interpersonal perspectives.

Narrator is "the person who articulates ('speaks') the narrative text" [Jahn, 2017]. Stories about a city's history may be narrated by eyewitnesses or stem from old people's memories handed down from one generation to another; they can be told by third parties - historians, writers, poets, children, foreign tourists, singers as personifiers of the author, etc. It is interesting that English-language posters in some Chinese museums present their tour guides as "narrators".

It is up to the narrator how to tell the story, which events to include, emphasise or mention only briefly. The content can depend on the narrator's competence and educational level, knowledge about the city or the ability to tell a coherent story. A good example is the family saga told at the Shi's Court (石家大院), a luxurious residence complex of a successful business family, in Tianjin. As the Shi family lived there for over two hundred years and experienced settlement, prosperity and decline, the narrator has a wide range of stories to choose from.

The exploitation of historical narratives to promote political views is a common practice. Politicians use narratives to appropriate or reshape the past and the present - a common form of manipulation when certain facts are unduly exaggerated and others diminished or altogether ignored.

The audience is represented by readers of historical books - both documentary and fictional; listeners in a classroom or during a meeting; tourists participating in a guided city tour; film viewers; consumers of mass media, etc. A narrative is usually adapted for the audience, taking into account its interests, age, educational level and other social characteristics relevant for adequate communication. An illustration is the Zhou Enlai-Deng \& Yingchao Museum, a national base for patriotic education, in Tianjin, where the narrative of two leading figures, a couple, in Twentieth-Century Chinese history, caters to pupils and students of different age; or the Panorama of the Stalingrad Battle which offers special programs for adults, schoolchildren, students and war veterans. 
Plot. Historical narratives are generally based on real events. However, multiple narratives can provide different urban history interpretations. They can be related not only with the help of words but also images, streets, monuments, artefacts, exhibitions and paintings. R. Walsh writes about "the vast capacity for elaboration that makes narrative such a ubiquitous presence in culture and daily life" [Walsh, 2019, p. 79].

The construction of a narrative is connected with such universal communication mechanisms as the filtering of information, articulation of certain facts and perceptions over others and reflexivity from a particular angle. The perspective, therefore, plays a defining role in the way the information is presented (e. g. the account of the Stalingrad battle by Russians vs. Germans; or the events of the Second Sino-Japanese War told by the Chinese vs. Japanese).

Whereas historians, writers, university professors and tour guides produce elaborate narratives with lots of tiny details (figures, facts, toponyms and anthroponyms), common people's stories are condensed versions of what they read in books or hear from specialists. They are characterized by the loss of details and generalization of knowledge limited by the capacity of human memory. It is such narratives based on the most intensely remembered facts, coloured with emotions and intensified by visual images and impressions that most likely make history in the minds of general public.

Time is another important narrative dimension. An interesting feature of urban historical memories is that they do not possess fixed temporal boundaries - the author decides where to start and end the narration. Here comes the differentiation between story time versus discourse time, the former being the actual duration of an event and the latter - the length of time the narrator needs to relate about it. Some narratives are condensed versions of others devoid of historical details. Narratives also reflect the dynamics of a city in time. New events and social practices, such as "The Immortal Regiment", a huge march of people carrying the portraits of their relatives who participated in World War II, which originated in Russia in 2014, account for the re-emergence of old narratives and their reconceptualization.
Human memory is linked to space. Urban space is used to create values, beliefs and ideologies. Out of the three historical names of Volgograd, two are based on its geographical position: Tsaritsyn possibly stems from the Tartar words 'yellow sand' or 'yellow river' and Volgograd - from the city's position on the bank of the Volga River.

Emperor Yongle established a fort in Tianjin and after he moved the capital of the Ming Dynasty from Nanjing to Beijing in 1421, Tianjin became a fortress in defence of the capital, hence the city is also known as "Tianjin Wei" (天津卫). Present street names (the East Road, the South Road, the West Road, the North Road, and the four corners) still clearly define the old town in spite of very few relics or architecture. Since Beijing has been the capital of China most of the time from then on and Tianjin is only approximately 120 kilometres to its southeast, adjacent to the sea and rivers, the name of "Tianjin Wei" remains popular and is even elaborated by the municipal leaders as a fortress of security, ideology and ecology for Beijing. At the same time, many places are named as $\mathrm{Gu}$ (沽), in association with river or water, as the city is at the lower stretch of nine rivers and is known as "a city with seventy-two Gu” (七十二沽) .

Haidu points out that "mental mapping is regarded as a basic cognitive strategy of the human mind, which is connected to space" [Haidu, 2019, p. 67]. In both Tianjin and Volgograd memories are reflected in road directions, attraction signs, logical and chronological connections between the main places of interest, routes of guided tours, etc. Consumption places, such as restaurants, cafes and shops, are built into the landscape exploiting historical memories. Examples are the Tsaritsyn shopping centre, Tsaritsyn Opera and Old Stalingrad hotel in Volgograd; the Used Clothes Street (故衣街), the Ancient Culture Street (古文化街), the Food Castle (食品街), the Gobuli Restaurant for stuffed bun (狗不理包子), the Deep-fried Dough Twist Snack in the $18^{\text {th }}$ Street (十八街麻花) and the Fried Rice Cake at the Ear Lane (耳朵眼炸糕) in Tianjin.

The semiotic signs used to represent memories in a city's landscape include: urban toponyms and anthroponyms; architecture; street signs, slogans, advertisements; souvenirs; inscriptions on T-shirts and caps; names and 
decoration of local foodstuffs, restaurants and cafes; titles of books and films; names and format of organized events and communication practices. Virtually anything can trigger the unfolding of a narrative - an artefact, a guide book, a mention of something in a conversation producing a complex chain of associations. An interesting example in Tianjin is the cross above the entrance to the Hoangho-Paiho Museum of Natural History designed by its French missionary founder that is not removed even though the museum stands on the campus of a public university. Another important semiotic sign is music, like the symbolic use of Robert Schumann's Traumerei in the Hall of Soldier's Glory on Mamayev Hill, the key historical attraction in Volgograd, indicating that during the Second World War Russians fought Nazis, not Germans.

Language as a semiotic system plays an important role; it expresses the attitude towards historic events; fills narratives with the national spirit and a variety of connotations; provides a choice between archaisms and historisms, on the one hand, and modern terms, on the other, the latter used in order to conceptualise the city's history through the prism of modern perceptions and bring memories closer to the young generation. The use of stylistic devices reflects the emotional tension of the events, the narrator's empathy or disapproval, historical value and present-day attitude.

Intertextual connections are realized through cross-references to narratives of different nature, the interplay between the past and the present, presuppositions, inferences, allusions and complex association chains. A Volgograd example is Mamayev Hill, which is associated with the narratives about Khan Mamay's invasion in the $14^{\text {th }}$ century, fierce fighting in 1942-1943 and the tourist pilgrimage in modern times. In Tianjin, intertextual connections can be traced through ancient couplets, poems and narratives built into parks and other public landscapes, such as the "Narrative of Sancha Estuary, or the Three Converging Estuaries" (《三岔河口记》) carved on the bank; and integration of modern socialist values with traditional culture as the line of the Chinese Communist party represented in ubiquitous social advertising of the "core socialist values" in twentyfour characters.

\section{Discussion and conclusions}

The goal of the paper was to reveal the role of urban historical narratives in shaping the image of a big city and lay out theoretical foundations for their further study. We proceed from the idea about the textuality of the human mind and the narrative ways of reality and identity construction. The study allows us to draw the following conclusions.

1. Narratives which preserve urban memories can be presented not only in the form of words but also images, streets, monuments, artefacts, exhibitions and paintings. They possess culture-specific peculiarities embedded in the landscape, architecture, climate, traditions and language.

2. The construction of a narrative is based on such universal communication mechanisms as the filtering of information, articulation of certain facts and perceptions over others and reflexivity from a particular angle. Therefore, multiple narratives can provide different urban history interpretations.

3. A specific feature of urban historical narratives is that they do not possess fixed temporal boundaries - the author decides where to start and end the narration. They also change due to the dynamics of urban social life.

4. Space and its organization play an important role in the cognitive mapping of the urban landscape and its links to the past. The names of consumption places, such as restaurants, cafes and shops, are often used to exploit historical memories.

5. Whereas historians, writers, tour guides and other specialists produce elaborate narratives with lots of factual details, the stories that shape memories in the minds of general public are their condensed versions based on the most intensely remembered facts, coloured with emotions and intensified by visual images and impressions.

6. Intertextual connections are achieved through cross-references to narratives of different nature, the interplay between the past and the present, presuppositions, inferences, allusions and complex association chains.

The research shows that urban narratives both in Volgograd and Tianjin possess great social value, as they: 1) preserve historical memories; 2) form links between the past and the present; 3 ) shape 
the city's image; 4) create communal feelings and sense of belonging; 5) play an important role in educating young people; 6) disseminate knowledge about the city, its culture and values. These findings may lead to their practical application and help urban communities realize the significance of historical narratives and the responsibility of those who reproduce memories in the form of books, artwork, documentaries, fiction films and street advertising. It is most likely that those images will stick in the memory the city's inhabitants and define their identity. The perspective of the research is to investigate the connection of these processes with Russian and Chinese mentality, values, logic of meaning-making and linguistic expression.

\section{REFERENCES}

Aiello G., Tosoni S., 2016. Going About the City: Methods and Methodologies for Urban Communication Research. International Journal of Communication, no. 10, pp. 1252-1262.

Bakumova E.V., 2018. Mediurbanistika: formy i yazykovoe vyrazhenie (na materiale kommunikativnykh praktik Volgograda) [Media Urban Studies: Forms and Linguistic Expression (On the Material of Communication Practices in Volgograd)]. Filologiya $v$ XXI veke [Philology in the $21^{\text {st }}$ Century], no. 2, pp. 29-34.

Bordwell D., Thompson K., 2004. Film Art: An Introduction. Boston, McGraw-Hill. $519 \mathrm{p}$.

Dickinson G., 1997. Memories for Sale: Nostalgia and the Construction of Identity in Old Pasadena. The Quarterly Journal of Speech, vol. 83, no. 1, pp. 1-27.

Genette G., 1976. Boundaries of Narrative. New Literary History, vol. 8, no. 1, pp. 1-13.

Hajdu P., 2019. Narrative Landscapes in Classical Texts. The $7^{\text {th }}$ International Conference on Narratology and the $9^{\text {th }}$ National Seminar on Narratology. Nanchang, October 2019. Nanchang, vol. 1, pp. 67-73.

Ilyin I. P., 2001. Postmodernizm: slovar terminov [Postmodernism: Glossary of Terms]. Moscow, INION RAN-INTRADA. 384 p.

Jahn M., 2017. Narratology: A Guide to the Theory of Narrative. Cologne, University of Cologne. URL: http://www.uni-koeln.de/ ame02/pppn.htm.
Kotelnikova N., Bakumova E., 2019. Linguistic Expression of the Social Stratification of Chinese Urban Society. SHS Web of Conferences (The International Scientific and Practical Conference "Current Issues of Linguistics and Didactics: The Interdisciplinary Approach in Humanities and Social Sciences").Volgograd, April 23-28, 2019. Volgograd, vol. 69, 00011. DOI: https://doi.org/10.1051/shsconf/20196900011.

Kotelnikova N., 2019. Molodezhnye subkultury v mediaurbanisticheskom prostranstve sovremennogo kitayskogo goroda [Youth Subcultures in the Urban Space of a Modern Chinese City]. Gumanitarnye issledovaniya v Vostochnoy Sibiri i na Dalnem Vostoke [Humanitarian Research in Siberia and Far East], no. 1 , pp. 25-32.

Leontovich O., 2018. The All-Seeing Eye of the City from the Perspective of Urban Communication Studies. Vestnik Volgogradskogo gosudarstvennogo universiteta. Seriya 2. Yazykoznanie [Science Journal of Volgograd State University. Linguistics], vol. 17, no. 4, pp. 206-213. DOI: https://doi.org/10.15688/ jvolsu2.2018.4.20.

Leontovich O., 2019a. New Forms of Urban Discourse as a Reflection of Social Change. Kommunikativnye issledovaniya [Communication Studies], vol. 6, no. 3, pp. 645-654.

Leontovich, O., 2019b. The Semiotic Landscape of Volgograd in the Context of Urban Communication Studies. Journal of Siberian Federal University. Humanities \& Social Sciences, vol. 12, no. 1, pp. 97-105.

Lyotard J.-F., 1998. Sostoyanie postmoderna [The Postmodern Condition]. Saint Petersburg, Aleteya Publ. 160 p.

Modan G., 2017. New Urban Chic: The Semiotic Landscape of Gentrification in US Cities. Abstracts of the Conference "City Talk: Urban Identities, Mobilities and Textualities". Bern, December 11-12, 2017. Bern, 2017, p. 15.

Pradl G. Narratology: The Study of Story Structure. ERIC Digest. URL: http://www.ericdigests. org/ pre-921/story.

Walsh R., 2019. Criteria of Human and AI Narrative Competence. The $7^{\text {th }}$ International Conference on Narratology and the $9^{\text {th }}$ National Seminar on Narratology. Nanchang, October 2019. Nanchang, vol. 1, pp. 79-86. (in Chinese). 


\section{Information About the Authors}

Chen Fachun, Doctor of Literature, Professor, President of Tianjin Foreign Studies University, Machang Road, 117, Tianjin, China, fachunchen@tjfsu.edu.cn

Olga A. Leontovich, Doctor of Sciences (Philology), Professor, Head of the Department of Intercultural Communication and Translation, Volgograd State Socio-Pedagogical University, Prosp. Lenina, 27, 400066 Volgograd, Russia; Professor, Tianjin Foreign Studies University, Machang Road, 117, Tianjin, China, olgaleo@list.ru, https://orcid.org/0000-0002-0972-4609

\section{Информация об авторах}

Чэнь Фачунь, доктор литературы, профессор, президент Тяньцзиньского университета иностранных языков, ул. Мачандао, 117, г. Тяньцзинь, Китай, fachunchen@tjfsu.edu.cn

Ольга Аркадьевна Леонтович, доктор филологических наук, профессор, заведующая кафедрой межкультурной коммуникации и перевода, Волгоградский государственный социально-педагогический университет, просп. Ленина, 27, 400066 г. Волгоград, Россия; профессор, Тяньцзиньский университет иностранных языков, ул. Мачандао, 117, г. Тяньцзинь, Китай, olgaleo@list.ru, https://orcid.org/0000-0002-0972-4609 